\title{
Celiac Disease and Risk of Atrial Fibrillation: A Meta-analysis and Systematic Review
}

Diego F. Hidalgo ${ }^{1}$, Boonphiphop Boonpheng ${ }^{2}$, Lubna Nasr ${ }^{3}, 4$, Sehrish Sikandar ${ }^{4}$, Jessica Hidalgo ${ }^{5}$, Maria Intriago 6

1. Geriatrics, Jackson Memorial Hospital, University of Miami, Miami, USA 2. Internal Medicine, East Tennessee State University, Johnson City, USA 3. Geriatrics, University of Miami Miller School of Medicine, Miami, USA 4. Geriatrics, Miami VAHS GRECC Veterans Successful Aging for Frail Elders (VSAFE), Miami, USA 5. Internal Medicine, San Francisco de Quito University, Quito, ECU 6. Medicina, Universidad Espiritu Santo, Guayaquil, ECU

Corresponding author: Diego F. Hidalgo, dhidalgo014@gmail.com

\section{Abstract}

\section{Introduction}

Several studies have found celiac disease may be associated with a variety of cardiac manifestations. Atrial fibrillation (AF) is one of the most common arrhythmias that can cause significant morbidity. However, the risk of atrial fibrillation in patients with celiac disease according to epidemiological studies remains unclear. The aim of this meta-analysis study is to assess the risk of atrial fibrillation in patients diagnosed with celiac disease compared to controls.

\section{Methods}

A systematic literature review was conducted in MEDLINE, EMBASE, Cochrane databases from inception through December 2017 to identify studies that evaluated the risk of atrial fibrillation in patients with celiac disease. We included randomized controlled trial, cross sectional and cohort studies that reported the odds ratio, relative risk, hazard ratio, and standardized incidence ratio comparing the risk of developing atrial fibrillation among patients with celiac disease, versus patients without celiac disease as control. The Newcastle-Ottawa scale was used to determine the quality of the studies. Effect estimates from individual studies were extracted and combined using random-effect, generic inverse variance method of DerSimonian and Laird.

\section{Results}

Celiac disease is an autoimmune condition. This inflammatory state predisposes patients to develop AF. After a review of the literature, four observational studies with a total of 64,397 participants were enrolled. The association between celiac disease and increased risk of atrial fibrillation was significant, with a pooled OR of 1.38 (95\% CI: 1.01-1.88). No publication bias as assessed by the funnel plots and Egger's regression asymmetry test with $\mathrm{p}=0.54$. However, the heterogeneity of the included studies was high $(\mathrm{I} 2=96)$.

Received 01/23/2020

Review began $02 / 02 / 2020$ Review ended 02/10/2020 Published 02/14/2020

\section{() Copyright 2020}

Hidalgo et al. This is an open access article distributed under the terms of the Creative Commons Attribution License CC-BY 4.0., which permits unrestricted use, distribution, and reproduction in any medium, provided the original author and source are credited.

\section{Conclusion}

A significant association between celiac disease and risk of atrial fibrillation was reported in this study. There is a $38 \%$ increased risk of atrial fibrillation. Additional studies are needed to clarify the mechanistic link between atrial fibrillation and celiac disease. Some of the limitations of this study are that all were observational studies, some were medical registry-based and there was high heterogeneity between studies.

Categories: Cardiology, Internal Medicine, Gastroenterology

Keywords: celiac disease, atrial fibrillation, gluten sensitivity, inflammation

\section{Introduction}

Celiac disease (CD) is an autoimmune, multisystemic and chronic disorder characterized by inflammation and villous atrophy in the small intestine in individuals with genetic susceptibility to gluten [1]. The incidence in the United States is approximately $1 \%$ ( 0.1 celiac patient per 1000 live births), similar to many countries in Europe [2,3].

Patients with CD may have intestinal and extraintestinal manifestations. Intestinal manifestations include malabsorption, abdominal distention and diarrhea. Some of the most common extraintestinal manifestations are characterized by fatigue, osteoporosis, reproductive, neuropsychiatric, immune disorders including diabetes mellitus, and malignant neoplasm of the gastrointestinal system [4-6].

Also, many studies have reported cardiovascular diseases in individuals with $\mathrm{CD}$, such as cerebrovascular events, cardiomyopathy, ischemic heart disease and atrial fibrillation (AF) [7-9]. These cardiovascular 
disorders including AF could be related to inflammation and oxidative stress present in individuals with CD [10]. This has been proven by atrial electro-mechanic delay (EMD) as an early marker of AF and cardiac fibrosis seen in many biopsies [11-13].

AF is one of the most common arrhythmias that can cause significant morbidity. There is an estimation of 2.7-6.1 million people in the United States with AF [14]. However, the risk of AF in patients with CD according to epidemiological studies remains unclear.

The aim of this meta-analysis study is to assess the risk of atrial fibrillation in patients diagnosed with celiac disease compared to controls.

\section{Materials And Methods \\ Search strategy}

Two investigators (DH and $\mathrm{BB}$ ) personally reviewed the databases, MEDLINE, EMBASE and Cochrane from inception through December 2017 to identify studies that evaluated the risk of atrial fibrillation in patients with celiac disease. The search strategy included terms for 'atrial fibrillation, 'supraventricular tachycardia', 'tachyarrhythmia', 'gluten enteropathy', 'gluten sensitive’ and 'celiac disease'.

\section{Selection criteria}

Any study, in order to be selected for this meta-analysis, had to fulfill the following parameters:

- Randomized controlled trial (RCT), cohort (either prospective or retrospective), case-control study or cross-sectional study published as original study in the databases used. These studies should investigate the risk of developing AF in patients diagnosed with celiac disease.

- Odds ratios (OR), relative risk (RR), hazard ratio (HR), and standardized incidence ratio (SIR) with 95\% confidence intervals (CIs).

- Subjects without celiac disease were used as comparators in cohort and cross-sectional study.

In order to evaluate the quality of each study, the investigators independently used the validated NewcastleOttawa quality assessment scale (Figure 1). This scale evaluated each study in terms of selection of the participants, comparability between groups, as well as the ascertainment of the exposure of interest for case-control studies, and the outcome of interest for cohort studies [15]. 


\section{Cureus}

\section{NEWCASTLE - OTTAWA QUALITY ASSESSMENT SCALE} CASE CONTROL STUDIES

Note: A study can be awarded a maximum of one star for each numbered item within the Selection and Exposure categories. A maximum of two stars can be given for Comparability.

\section{Selection}

1) Is the case definition adequate?

a) yes, with independent validation

b) yes, eg tecord linkage or based on self reports

c) no description

2) Representativeness of the cases

a) consecutive or obviously representative series of cases

b) potential for selection biases or not stated

3) Selection of Controls

a) community controls

b) hospital controls

c) no description

4) Defirition of Controls

a) no history of disease (endpoint)
b) no description of source

\section{Comparability}

1) Comparability of cases and controls on the basis of the design or analysis
a) study controls for
(Select the most important factor.)
b) study controls for any additional factor (This criteria could be modified to indicate specific control for a second important factor.)

\section{Exposure}

1) Ascertainment of exposure
a) secure record (eg surgical records)
b) structured interview where blind to case/control status
c) interview not blinded to casc/control status
d) written self report or medical record only
e) no description

2) Same method of ascertainment for cases and controls
a) yes
b) no

3) Non-Response rate
a) same fate for both groups
b) non respondents described
c) rate different and no designation

\section{FIGURE 1: Newcastle-Ottawa quality assessment scale}

Adapted from [16].

\section{Data extraction}

A Microsoft Excel (Microsoft Corporation, Redmond, Washington, USA) data collection form was used to summarize the most relevant information obtained from these studies. This table contained the first author's last name, the country where the study was conducted, year of publication, demographics, the Newcastle-Ottawa quality assessment scale, the total number of participants, characteristics of the participants, the method used to diagnose atrial fibrillation, the method used to determine celiac disease, adjusted effect estimates with $95 \% \mathrm{CI}$, and covariates that were adjusted in the multivariate analysis (Table 1).

\begin{tabular}{|c|c|c|c|c|}
\hline & Lebwohl et al. [17] & $\begin{array}{l}\text { Pattanshetty } \\
\text { et al. [18] }\end{array}$ & Emilsson et al. [6] & West et al. [19] \\
\hline Country & USA & USA & Sweden & United Kingdom \\
\hline Study & Cohort & Cohort & Cohort & Cohort \\
\hline
\end{tabular}




\section{Cureus}

\begin{tabular}{|c|c|c|c|c|}
\hline Year & 2015 & 2014 & 2011 & 2004 \\
\hline $\begin{array}{l}\text { Number of } \\
\text { participants }\end{array}$ & 7440 & 24530 & 28637 & 3790 \\
\hline Participants & $\begin{array}{l}\text { Pathology reports from } 28 \\
\text { pathology centers in Sweden } \\
\text { between 2006-2008. Showing } \\
\text { villous atrophy. Patients with } \\
\text { CD who underwent more than } \\
\text { one duodenal biopsy. CD } \\
\text { patients who underwent } \\
\text { follow-up biopsy between six } \\
\text { months and five years after } \\
\text { initial CD diagnosis. }\end{array}$ & $\begin{array}{l}\text { Among a total } \\
\text { of } 22,385,340 \\
\text { patients, } \\
24,530 \text { were } \\
\text { diagnosed with } \\
\text { CD. The } \\
\text { remaining } \\
22,360,810 \\
\text { patients } \\
\text { without CD } \\
\text { served as the } \\
\text { control group. }\end{array}$ & $\begin{array}{l}29,148 \text { patients with CD through computerized } \\
\text { biopsy reports from all of the } 28 \text { Swedish } \\
\text { pathology departments. The biopsies were } \\
\text { obtained from } 1968 \text { to } 2008 \text {. A total of } 459 \\
\text { patients were excluded as they developed afib } \\
\text { before the time of the biopsy. }\end{array}$ & $\begin{array}{l}\text { All subjects within } \\
\text { the General Practice } \\
\text { Research Database } \\
\text { between June } 1987 \\
\text { and April } 2002 \text { with } \\
\text { a recorded } \\
\text { diagnosis of coeliac } \\
\text { disease aged } 25 \text { or } \\
\text { older at the start of } \\
\text { their GPRD record. }\end{array}$ \\
\hline $\begin{array}{l}\text { Mean age } \\
\text { of } \\
\text { participants } \\
\text { in years }\end{array}$ & NA. $46 \%$ were between $0-19$ & NA & 30 & NA \\
\hline $\begin{array}{l}\text { Percentage } \\
\text { of female }\end{array}$ & $64 \%$ & $61 \%$ & $62.2 \%$ & $68.6 \%$ \\
\hline $\begin{array}{l}\text { Diagnosis } \\
\text { of afib }\end{array}$ & NA & NA & $\begin{array}{l}\text { Diagnosis of AF: according to relevant ICD } \\
\text { codes in the Swedish National Patient Register } \\
\text { (Discharge diagnoses) and the Cause of Death } \\
\text { Register, the definition of AF included } \\
\text { inpatients and outpatients, as well as } \\
\text { individuals diagnosed with AF as a cause of } \\
\text { death. We included primary and secondary } \\
\text { diagnosis of AF from the Swedish Patient } \\
\text { Register, but only AFs that were listed as the } \\
\text { main underlying cause of death. }\end{array}$ & $\begin{array}{l}\text { Records review } \\
\text { from the GPRD that } \\
\text { included atrial } \\
\text { fibrillation as a } \\
\text { diagnosis after } \\
\text { Celiac disease was } \\
\text { diagnosed. }\end{array}$ \\
\hline $\begin{array}{l}\text { Diagnosis } \\
\text { of celiac } \\
\text { disease }\end{array}$ & $\begin{array}{l}\text { Small intestine biopsy } \\
\text { showing villous atrophy }\end{array}$ & NA & $\begin{array}{l}\text { Intestinal biopsy reports (defined as Marsh 3: } \\
\text { villous atrophy) from all pathology } \\
\text { departments (n. 28) in Sweden. }\end{array}$ & $\begin{array}{l}\text { Records review } \\
\text { from the GPRD that } \\
\text { included the } \\
\text { diagnosis of coeliac } \\
\text { disease aged } 25 \text { or } \\
\text { older. }\end{array}$ \\
\hline $\begin{array}{l}\text { Adjusted } \\
\text { OR or HR } \\
\text { or IRR }\end{array}$ & $\begin{array}{l}\text { Adjusted HR 0.97; } 95 \% \text { Cl } \\
0.73-1.30)\end{array}$ & $\begin{array}{l}\text { Odds ratio } \\
\text { being } 2.04 \\
\text { (95\% } \mathrm{Cl} 1.9 \text { to } \\
2.2) . \mathrm{P}<0.001\end{array}$ & $\begin{array}{l}\text { Adjusted HR for AF was } 1.34(95 \% \mathrm{Cl} 1.24- \\
1.44) . \mathrm{P}<0.001\end{array}$ & $\begin{array}{l}\text { Adjusted odds ratio } \\
1.26(95 \% \\
\text { confidence interval: } \\
0.97-1.64)\end{array}$ \\
\hline $\begin{array}{l}\text { Confounder } \\
\text { adjustment }\end{array}$ & $\begin{array}{l}\text { Age, gender, duration of } \mathrm{CD} \text {, } \\
\text { calendar period, educational } \\
\text { attainment. }\end{array}$ & $\begin{array}{l}\text { Sex, age, race, } \\
\text { DMII, HTN, } \\
\text { Smoker. }\end{array}$ & $\begin{array}{l}\text { Education, country of birth (Nordic country vs. } \\
\text { not Nordic country), type } 1 \text { diabetes, } \\
\text { autoimmune thyroid disease, or rheumatoid } \\
\text { arthritis, birth weight, BMI, antihypertensive } \\
\text { medication. }\end{array}$ & $\begin{array}{l}\text { Height, weight, } \\
\text { smoking, BMI, } \\
\text { diabetes type II, } \\
\text { thyroid disease. }\end{array}$ \\
\hline $\begin{array}{l}\text { Quality } \\
\text { assessment } \\
\text { (Newcastle- } \\
\text { Ottawa } \\
\text { scale) }\end{array}$ & $\begin{array}{l}\text { Selection: } 3 \text {, Comparability: } 1 \text {, } \\
\text { Outcome: } 3\end{array}$ & $\begin{array}{l}\text { Selection: } 4 \text {, } \\
\text { Comparability: } \\
\text { 1, Outcome: } 2\end{array}$ & Selection: 4, Comparability: 1, Outcome: 2 & $\begin{array}{l}\text { Selection: } 4 \text {, } \\
\text { Comparability: } 1 \text {, } \\
\text { Outcome: } 2\end{array}$ \\
\hline
\end{tabular}

\section{TABLE 1: Characteristics of studies included}

CD: Celiac Disease; afib, AF: Atrial Fibrillation; GPRD: General Practice Research Database; DMII: Diabetes Mellitus Type 2; HTN: Hypertension; BMI: Body Mass Index; ICD: International Classification of Diseases. 
To ensure accuracy, all investigators performed the data extraction process independently. Any data discrepancy was also resolved by referring back to the original article.

\section{Statistical analysis}

Data analysis was performed using Review Manager 5.3 software from the Cochrane Collaboration (London, United Kingdom). Adjusted point estimates and standard errors from the individual studies were combined using the generic inverse variance method of DerSimonian and Laird, which assigned the weight of each study based on its variance [20]. In light of the possible high between-study variance due to different study designs and populations, we used a random-effect model rather than a fixed-effect model. Cochran's $Q$ test and I2 statistic were used to determine the between-study heterogeneity. A value of I2 of $0 \%-25 \%$ represents insignificant heterogeneity, greater than $25 \%$ but less than or equal to $50 \%$ represents low heterogeneity, greater than $50 \%$ but less than or equal to $75 \%$ represents moderate heterogeneity, and greater than $75 \%$ represents high heterogeneity [21].

\section{Results}

An advanced search yielded 234 articles on the databases. Eight additional articles were identified through other sources. After the exclusion of eight articles that were duplicated, 234 underwent a title and abstract review. A total of 226 articles were excluded, as they were case reports, book articles, letters to the editor, or review articles without the information needed for the analysis, leaving eight articles for a full-length article review. A total of four articles were dismissed at this time because they did not have comparators. A total of four studies were used for statistical analysis, all of them were cohort studies. The outlines of the literature review and study selection process are given in Figure 2. The clinical characteristics of each study and the quality assessment are described in Table 1.

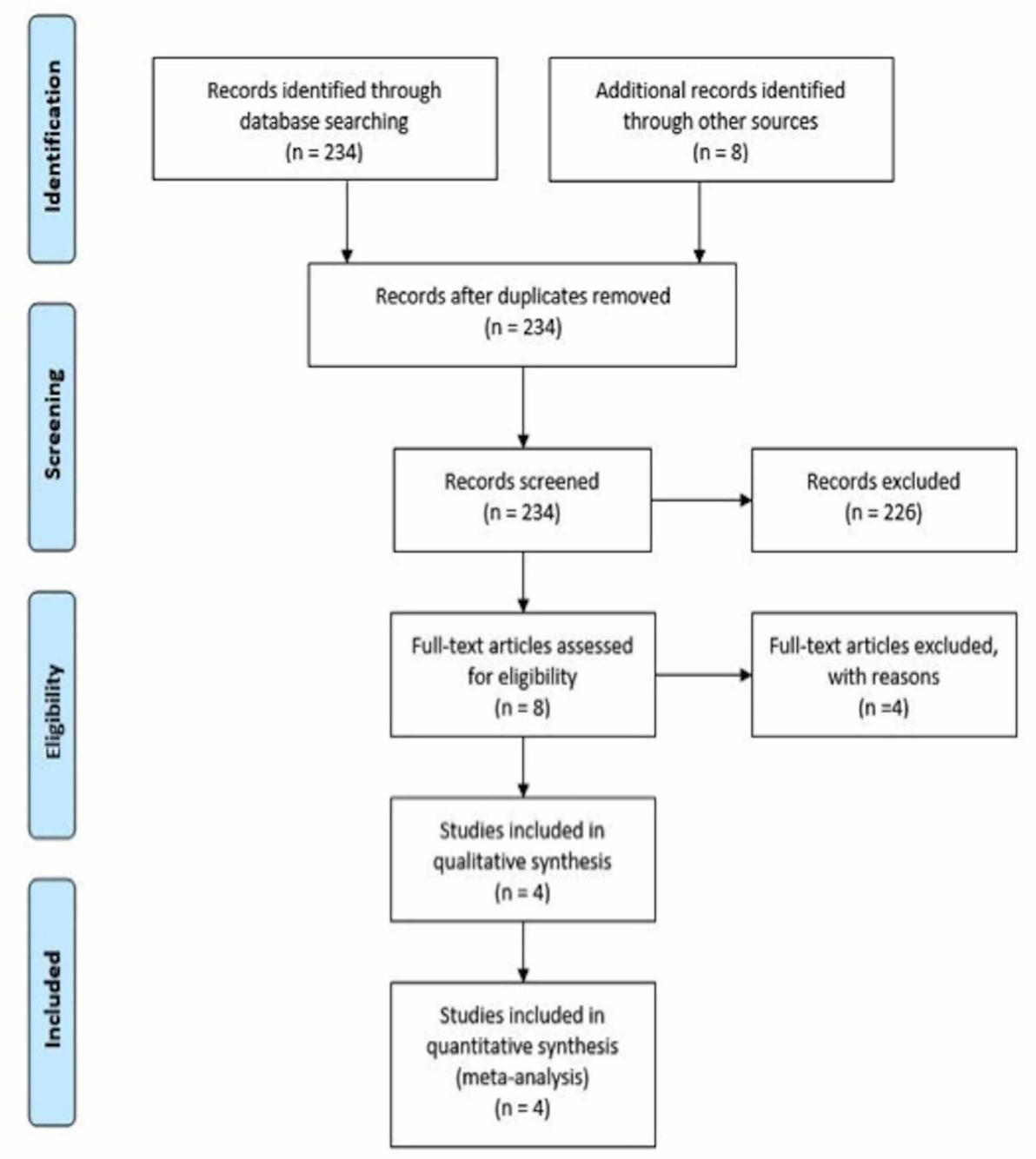

FIGURE 2: Search criteria and eligibility.

The overall analysis found a higher risk of atrial fibrillation in patients with celiac disease as compared with 
the control individuals who did not have celiac disease. The odds ratio (OR) was 1.38 (95\% CI: 1.01-1.88), p < 0.001, as shown in Figure 3.

\begin{tabular}{lrrrrrr} 
Study name & \multicolumn{6}{c}{ Statistics for each study } \\
& $\begin{array}{r}\text { Odds } \\
\text { ratio }\end{array}$ & $\begin{array}{c}\text { Lower } \\
\text { limit }\end{array}$ & $\begin{array}{l}\text { Upper } \\
\text { limit }\end{array}$ & Z-Value p-Value \\
West et al. 2004 & 1.26 & 0.97 & 1.64 & 1.73 & 0.08 \\
Emmilson et al. 2011 & 1.34 & 1.24 & 1.44 & 7.67 & 0.00 \\
Pattanshetty et al. 2014 & 2.04 & 1.90 & 2.20 & 19.06 & 0.00 \\
Lewbohl et al. 2015 & 0.97 & 0.73 & 1.29 & -0.21 & 0.84 \\
& 1.38 & 1.01 & 1.88 & 2.04 & 0.04
\end{tabular}



FIGURE 3: Relative risk and $p$-value.

To measure heterogeneity among the studies, Cochran's Q test and I2 were calculated. The I2 calculated for this study was 96, which represents high heterogeneity among the studies.

The Egger regression test and funnel plots were used to assess publication bias. Egger's regression test ( $\mathrm{P}$ 0.54 ) did not show a publication bias. Funnel plots (Figure 4) were symmetrical, indicating low publication bias. The total number of studies was four, which correlates with adequate power for this test.

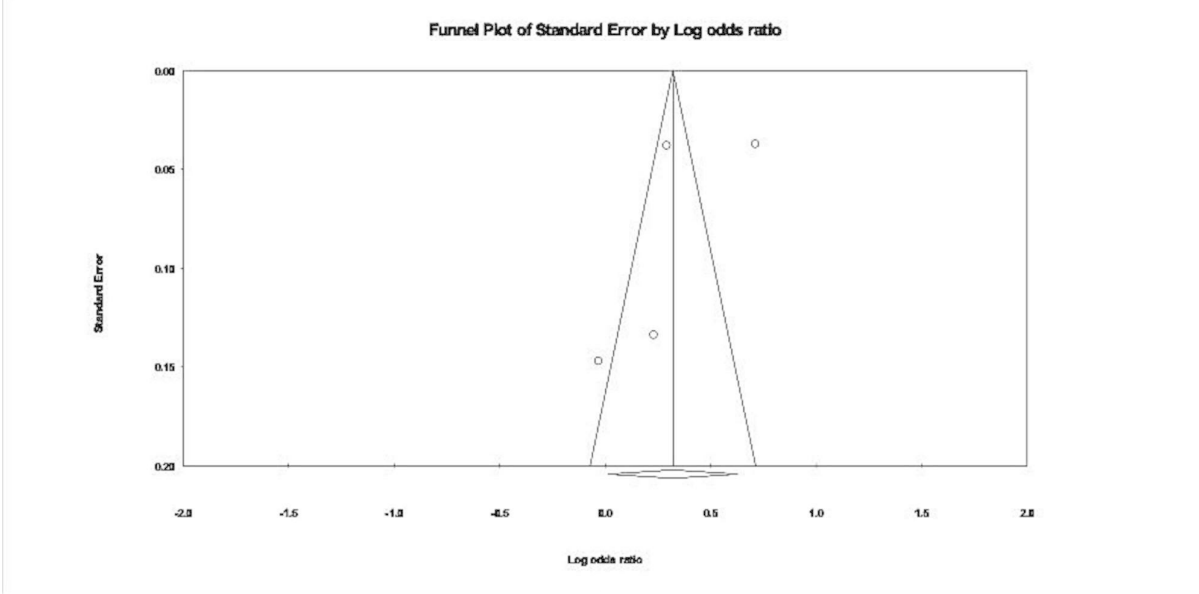

FIGURE 4: Publication bias, funnel plot.

\section{Discussion}

This meta-analysis study was performed to assess the risk of AF in patients diagnosed with $\mathrm{CD}$. After the evaluation of four studies that met the inclusion criteria (cohort, case-control and cross sectional), with a total enrollment of 64,397 participants, we found that patients with CD have a $38 \%$ increased risk of developing AF. This study represents the first meta-analysis that assesses the relationship between $\mathrm{CD}$ and AF.

This study would be considered global research because it includes countries around the world such as USA, UK, Sweden, and others. It collects more than 60,000 patients and their records. Also, we included studies correlating the risk of AF in patients with $\mathrm{CD}$ confirmed by biopsy [22,23]. Emilsson et al. reported that patients having a later diagnosis of $\mathrm{CD}$ were at increased risk of $\mathrm{AF}(\mathrm{OR}=1.45 ; 95 \% \mathrm{CI}=1.31-1.62)$. The results of this study are similar than earlier studies performed worldwide [6]. In 2004, West et al. reported an increased risk of $\mathrm{AF}$ in $\mathrm{CD}$ (OR 1.26; 95\% CI: 0.97-1.64) [18]. Both studies were similar to our findings ( $\mathrm{OR}=$ 1.38; $95 \%$ CI: 1.01-1.88). Those results compared with controls, confirm that CD is associated with significantly increased risk of AF.

Also, many studies have supported the role of the immune system in the pathophysiology of AF in patients with CD. Inflammation and oxidative stress have been found to be responsible of many molecular 
mechanisms of CD including activation of immune cells such as macrophages, $\mathrm{T}$ and B cells, neutrophils and inflammatory cytokines (IL-6, TNF- $\alpha$ ). These cytokines and activated immune cells could affect the contractility and electrical myocytes stability inducing fibroblast activation and cellular fibrosis [24-26]. These atrial changes provide reentrant arrhythmias confirmed clinically and electrocardiogram [27].

Regarding the strengths of this study, it includes research studies done all over the world, more than 60,000 patients were included and duplicated studies were removed. Among the limitations of this study: all were observational studies, some with medical registry-based, only four articles were included and there was high heterogeneity between these studies.

More studies should be done to determine the exact mechanism of how celiac disease increases the risk of atrial fibrillation. A good understanding of the mechanisms behind it could let us work more on preventive measures to decrease risk factors. Early identification, lifestyle modification, adherence and compliance to gluten-free diet, could slow the risk of AF in those patients with $\mathrm{CD}$. This work was presented as an abstract (https://eventscribe.com/2018/ACG/ajaxcalls/PosterInfo.asp? PosterID=161644\&efp=RFNSWFFHSFY2NDI0\&rnd=3.819197E-02)

\section{Conclusions}

A significant association between celiac disease and risk of atrial fibrillation was reported in this study. There is a $38 \%$ increased risk of atrial fibrillation in patients with celiac disease as compared to individuals without celiac disease used as controls. Additional studies are needed to clarify the mechanistic link between atrial fibrillation and celiac disease.

\section{Additional Information \\ Disclosures}

Human subjects: All authors have confirmed that this study did not involve human participants or tissue. Animal subjects: All authors have confirmed that this study did not involve animal subjects or tissue. Conflicts of interest: In compliance with the ICMJE uniform disclosure form, all authors declare the following: Payment/services info: All authors have declared that no financial support was received from any organization for the submitted work. Financial relationships: All authors have declared that they have no financial relationships at present or within the previous three years with any organizations that might have an interest in the submitted work. Other relationships: All authors have declared that there are no other relationships or activities that could appear to have influenced the submitted work.

\section{References}

1. Farrell RJ, Kelly CP: Celiac sprue. N Engl J Med. 2002, 346:180-188. 10.1056/NEJMra010852

2. Rubio-Tapia A, Ludvigsson JF, Brantner TL, Murray JA, Everhart JE: The prevalence of celiac disease in the United States. Am J Gastroenterol. 2012, 107:1538-1544. 10.1038/ajg. 2012.219

3. Feighery C: Coeliac disease. BMJ. 1999, 319:236-239. 10.1136/bmj.319.7204.236

4. Cronin C, Shanahan F: Insulin-dependent diabetes mellitus and coeliac disease. Lancet. 1997, 349:10961097. 10.1016/S0140-6736(96)09153-2

5. Catassi C, Fabiani E, Corrao G, et al.: Risk of non-Hodgkin lymphoma in celiac disease . JAMA. 2002, 287:1413-1419. 10.1001/jama.287.11.1413

6. Emilsson L, Smith JG, West J, Melander O, Ludvigsson JF: Increased risk of atrial fibrillation in patients with coeliac disease: a nationwide cohort study. Eur Heart J. 2011, 32:2430-2437. 10.1093/eurheartj/ehr167

7. Emilsson L, Andersson B, Elfström P, Green PH, Ludvigsson JF: Risk of idiopathic dilated cardiomyopathy in 29000 patients with celiac disease. J Am Heart Assoc. 2012, 1:e001594. 10.1161/JAHA.112.001594

8. Rosengren A, Hauptman PJ, Lappas G, Olsson L, Wilhelmsen L, Swedberg K: Big men and atrial fibrillation: effects of body size and weight gain on risk of atrial fibrillation in men. Eur Heart J. 2009, 30:1113-1120. 10.1093/eurheartj/ehp076

9. Efe TH, Ertem AG, Coskun Y, et al.: Atrial electromechanical properties in coeliac disease . Heart Lung Circ. 2016, 25:160-165. 10.1016/j.hlc.2015.08.003

10. Ferretti G, Bacchetti T, Masciangelo S, Saturni L: Celiac disease, inflammation and oxidative damage: a nutrigenetic approach. Nutrients. 2012, 4:243-257. 10.3390/nu4040243

11. Kannel WB, Wolf PA, Benjamin EJ, Levy D: Prevalence, incidence, prognosis, and predisposing conditions for atrial fibrillation: population-based estimates. Am J Cardiol. 1998, 82:2-9. 10.1016/s00029149(98)00583-9

12. Dzeshka MS, Lip GY, Snezhitskiy V, Shantsila E: Cardiac fibrosis in patients with atrial fibrillation: mechanisms and clinical implications. J Am Coll Cardiol. 2015, 66:943-959. 10.1016/j.jacc.2015.06.1313

13. Ludvigsson JF, James S, Askling J, Stenestrand U, Ingelsson E: Nationwide cohort study of risk of ischemic heart disease in patients with celiac disease. Circulation. 2011, 123:483-490. 10.1161/CIRCULATIONAHA.110.965624

14. Centers for Disease Control and Prevention. About multiple cause of death 1999-2018. CDC WONDER online database. (2014). Accessed: October 10, 2019: http://wonder.cdc.gov/mcd-icd10.html.

15. Stang A: Critical evaluation of the Newcastle-Ottawa scale for the assessment of the quality of nonrandomized studies in meta-analyses. Eur J Epidemiol. 2010, 25:603-605. 10.1007/s10654-010-9491-Z

16. Wells GA, Shea B, O'Connell D, Peterson J, Welch V, Losos M, Tugwell P: The Newcastle-Ottawa Scale (NOS) for assessing the quality of nonrandomised studies in meta-analyses. Ottawa Hospital Research Institute. 


\section{Cureus}

2014,

17. Lebwohl B, Emilsson L, Fröbert O, Einstein AJ, Green PHR, Ludvigsson JF: Mucosal healing and the risk of ischemic heart disease or atrial fibrillation in patients with celiac disease; a population-based study. PLos One. 2015, 10:e0117529. 10.1371/journal.pone.0117529

18. Pattanshetty D, Anna K, Gajulapalli RD, Sappati-Biyyani RR: Inflammatory bowel "Cardiac" disease: point prevalence of atrial fibrillation in inflammatory bowel disease population. Saudi J Gastroenterol. 2015, 21:325-329. 10.4103/1319-3767.166208

19. West J, Logan RF, Card TR, Smith C, Hubbard R: Risk of vascular disease in adults with diagnosed coeliac disease: a population-based study. Aliment Pharmacol Ther. 2004, 20:73-79. 10.1111/j.13652036.2004.02008.x

20. DerSimonian R, Laird N: Meta-analysis in clinical trials. Control Clin Trials. 1986, 7:177-188. 10.1016/01972456(86)90046-2

21. Higgins JP, Thompson SG, Deeks JJ, Altman DG: Measuring inconsistency in meta-analyses. BMJ. 2003, 327:557. 10.1136/bmj.327.7414.557

22. Danesh J, Wheeler J, Hirschfield G, et al.: C-reactive protein and other circulating markers of inflammation in the prediction of coronary heart disease. N Engl J Med. 2004, 350:1387-1397. 10.1056/NEJMoa032804

23. Smith JG, Newton-Cheh C, Almgren P, et al.: Assessment of conventional cardiovascular risk factors and multiple biomarkers for the prediction of incident heart failure and atrial fibrillation. J Am Coll Cardiol. 2010, 56:1712-1719. 10.1016/j.jacc.2010.05.049

24. Liu Y, Shi Q, Ma Y, Liu Q: The role of immune cells in atrial fibrillation . J Mol Cell Cardiol. 2018, 123:198208. 10.1016/j.yjmcc.2018.09.007

25. Lee SK, Lo W, Memeo L, Rotterdam H, Green PHR: Duodenal histology in patients with celiac disease after treatment with a gluten-free diet. Gastrointest Endosc. 2003, 57:187-191. 10.1067/mge.2003.54

26. Ramos-Mondragon R, Galindo CA, Avila G: Role of TGF- $\beta$ on cardiac structural and electrical remodeling . Vascular Health Risk Manag. 2008, 4:1289-1300. 10.2147/vhrm.s3985

27. Efe TH, Ertem AG, Coskun Y, et al.: Atrial electromechanical properties in coeliac disease . Heart Lung Circ. 2016, 25:160-165. 10.1016/j.hlc.2015.08.003 